\title{
Dampak Konflik Peran pada Stres dan Kepuasan Kerja Karyawan
}

\section{IMPACT OF ROLE CONFLICT ON JOB SATISFACTION, MEDIATING JOB STRESS IN PT. JOMBANG INTERMEDIA PERS (Jawa PoS RADAR JOMBANG)}

\author{
Kristin Juwita \\ STIE PGRI Dewantara Jombang \\ Devy Arintika \\ STIE PGRI Dewantara Jombang
}

*Corresponding author: E-mail: kristinjuwita66@gmail.com

\begin{abstract}
Abstrak
Penelitian ini bertujuan meneliti pengaruh konflik peran terhadap kepuasan kerja karyawan dengan stres kerja sebagai variabel mediasi pada PT. Jombang Intermedia Pers (Jawa Pos Radar Jombang). Jenis penelitian adalah penelitian penjelasan (explanatory research) dengan pendekatan kuantitatif. Pengumpulan data menggunakan kuesioner yang disebarkan kepada 30 karyawan PT.Jombang Intermedia Pers (Radar Jombang) dengan metode sampling jenuh. Metode analisis menggunakan SEM (Structural equation Model) dengan alat analisis Pls versi 3. Berdasarkan hasil penelitian menunjukan ada pengaruh positif yang signifikan antara konflik peran terhadap stres kerja. Namun, justru konflik peran berpengaruh positif terhadap kepuasan kerja, stres kerja berpengaruh positif terhadap kepuasan kerja, dan stres kerja tidak mampu memediasi antara konflik peran terhadap kepuasan kerja.
\end{abstract}

\section{Kata Kunci: Konflik Peran, Stres Kerja dan Kepuasan Kerja}

\begin{abstract}
The purpose of this research is to know the effect of role conflict on employee job satisfaction with job stress as a mediation variable at PT. Jombang Intermedia Press (Jawa Pos Radar Jombang). The research used explanatory research with a quantitative approach to explain the relationship between variables through hypothesis testing. This study uses questionnaires which is distributed to 30 respondents of PT. Jombang Intermedia Pers (Radar Jombang) with saturated sampling method. The analysis method uses SEM (Structural Equation Model) with PLS (partial least square) 3. The result of data analysis known has significant positive influence between role conflict on work stress. But, role conflict has a positive effect on job satisfaction, work stress positively influence to job satisfaction, while work stress is not able to mediate between role conflict to job satisfaction.
\end{abstract}




\section{Kerja Karyawan]}

\section{A. PENDAHULUAN}

Aktivitas sumber daya manusia dapat menentukan keberhasilan pencapaian tujuan perusahaan, karenanya manajemen harus memberi perhatian kepada sumber daya manusia agar kestabilan jalannya usaha senantiasa lancar. Salah satu faktor yang bisa memacu karyawan dalam mencapai tujuan perusahaan adalah kepuasan khususnya terhadap pekerjaannya. Kepuasan kerja adalah sikap emosional seseorang terhadap beberapa aspek pekerjaanya, (Kreitner dan Kinicki, 2014 dalam Widyani, A. D., \& Sugianingrat, I. W, 2015). Setiap individu memiliki tingkat kepuasan yang berbeda sesuai dengan perasaannya. Semakin banyak aspek-aspek dalam pekerjaan yang sesuai dengan keinginan individu, maka akan semakin tinggi tingkat kepuasan yang dirasakan, dan sebaliknya. Di dalam perusahaan, termasuk industri media cetak karyawan dituntut bekerja dengan profesionalisme tinggi. Tuntutan profesionalisme ini tercermin dari kepatuhan terhadap peraturan, budaya, norma, dan SOP (Standard Operation Procedure) yang ditetapkan perusahaan Akwan, N. M., Suprapti, N. W. S., \& Sintaasih, D. K. (2016). Namun, beberapa peraturan justru berpeluang menimbulkan konflik bagi karyawan khususnya terjadi konflik peran karena tidak sesuai dengan tata nilai, kebiasaan dan proses bekerja yang dilakukan sebelumnya dan berdampak pada stres dan kepuasan kerja karyawan.

\section{Konflik peran adalah kondisi seseorang pada tekanan untuk} mengerjakan beberapa pekerjaan yang berbeda dan tidak konsisten dalam waktu bersamaan, (Yustrianthe, R. H, 2008). Konflik peran muncul karena banyaknya pekerjaan yang kerjakan karyawan, Nur, I. R., Hidayati, T., \& Maria, S. (2017). Konflik peran menurut Robbins, SP. \& Judge, TA. (2009) akan menciptakan pengharapan- pengharapan yang sulit untuk dipenuhi atau dipuaskan. Konflik peran dapat menyebabkan terjadinya stres kerja dan menurunnya kepuasan kerja. Hal tersebut akan diperparah dengan adanya perasaan ketidakpastian karyawan terhadap organisasi. Ketidakpastian tersebut meliputi ketidakpastian dalam menjalankan tugas, adanya job insecurity serta ketidakpastian akan kesejahteraan diri. Perasaan tersebut akan menggangu karyawan saat bekerja yang dapat berpengaruh terhadap menurunnya kepuasan kerja dan meningkatnya stres kerja.

Stres kerja adalah situasi kerja menegangkan yang mempengaruhi emosi, proses berfikir dan kondisi seseorang, Handoko (2008). Stres atau perasaan tertekan dalam jiwa seorang karyawan berdampak pada kepuasan kerjanya. Akan tetapi, tidak semua karyawan yang mengalami stres dalam bekerja tidak mampu menyelesaikan pekerjaan tepat waktu dan sesuai dengan target yang telah ditetapkan. Afrizal, P. R. (2014). Stres di tempat kerja menurut Munandar (2010: 241) dalam Nur, I. R., Hidayati, T., \& Maria, S. (2017) disebabkan oleh beberapa faktor yang dapat diidentifikasikan oleh banyak peneliti, seperti ketidakamanan pekerjaan, konflik peran, ambiguitas peran, tekanan waktu, konflik interpersonal, jumlah pekerjaan yang berlebihan.

Berdasarkan hasil penelitian Iqbal, N. (2013) yang menunjukan pengaruh positif yang signifikan antara konflik peran dan stres kerja, konflik peran berpengaruh negatif dengan kepuasan kerja dan stres kerja, serta stres kerja memediasi antara konflik peran dan kepuasaan kerja. Namun, Safaria T et al., (2011) dalam Muhdiyanto, M., \& Hidayati, L. A. (2017) menunjukkan hasil yang berbeda, karena konflik peran tidak berpengaruh pada stres kerja. Pada hasil penelitian Yousef, D. A. (2000) 
menemukan bahwa konflik peran tidak memiliki efek interaktif pada kepuasan kerja, begitu pula pada Widyani, A. D., \& Sugianingrat, I. W. (2015). menemukan bahwa konflik peran tidak berpengaruh terhadap kepuasan kerja dan stres kerja tidak mampu menjadi mediasi antara konflik peran terhadap kepuasan kerja. Berdasarkan beberapa hasil penelitian ini menunjukkan hasil yang inkonsistensi.

Radar Jombang adalah salah satu dari 165 surat kabar yang ada di Indonesia (http://corporate.jawapos.com/businesssection\#business-section-media). Radar Jombang yang sebelumnya merupakan kantor biro Jombang untuk Radar Mojokerto telah berkembang menjadi PT. Jombang Intermedia Pers dan berpisah dari Radar Mojokerto termasuk karyawannya sebagian pindah ke Radar Mojokerto. Hal ini, tidak diimbangi dengan penambahan karyawan di kantor Radar jombang karena sumber daya manusia yang ada dimaksimalkan fungsinya yang berakibat kepuasan kerja karyawan yang menurun yang diindikasikan dengan karyawan mengalami kesulitan menyelesaikan berbagai pekerjaan sesuai target yang telah ditentukan perusahaan. Hal ini terjadi karena karyawan mengalami konflik peran yaitu kondisi konflik yang muncul ketika karyawan merasa kesulitan dalam hal menyesuaikan berbagai peran yang dimiliki dalam waktu yang bersamaan. Karyawan yang awalnya hanya memegang satu pekerjaan, saat ini dituntut untuk bisa menyelesaikan dua hingga tiga bidang pekerjaan sekaligus dalam waktu yang sama, yang sebenarnya tidak sesuai dengan deskripsi pekerjaan awal bidang kerja karyawan dan belum tentu karyawan mempunyai kemampuan di bidang tersebut.

Beban kerja dan tanggung jawab yang bertambah menyebabkan karyawan Radar Jombang merasa stres atau tertekan yang diindikasikan dengan karyawan kesulitan dalam memenuhi standard kinerja yang ditetapkan perusahaan karena bingung pekerjaan mana yang harus diselesaikan dahulu, kecemasan, tersinggung, mudah marah, jenuh, menangis hingga mengalami gangguan kesehatan.Stres yang meningkat dapat berdampak pada penurunan kepuasan karyawan Radar Jombang terhadap pekerjaan, rekan kerja, atasan, bahkan imbalan yang di terima.

\section{Rencana pemecahan masalah:}

Kepuasan kerja karyawan
merupakan faktor yang diperhatikan. Maka dari itu, dilakukan suatu kegiatan penilaian persepsi kepuasan kerja karyawan, yang diukur dari hubungan antara pimpinan dengan karyawan, pembagian tugas dan kesamaan atau kesesuaian program kerja, Afrizal, P. R. (2014).

\section{Rumusan Penelitian :}

Kepuasan kerja sering ditunjukkan oleh karyawan dengan caranya menyukai pekerjaan itu sendiri serta tingkat keasikannya dalam menjalankan pekerjaan. Demikian sebaliknya, ketidakpuasan kerja sering ditunjukan dengan banyaknya pelanggaran peraturan yang dilakukan pegawai serta tidak terlepas dari suatu keadaan yang mengikuti seorang individu salah satunya yaitu stres. Karyawan PT. Jombang Intermedia Pers (Jawa Pos Radar Jombang) mengalami konflik peran dan stress dalam menyelesaikan pekerjaannya. Karyawan dituntut untuk bisa menyelesaikan dua atau lebih bidang kerja dengan baik sesuai dengan prosedur yang telah ditetapkan sesuai dengan target sehingga menyebabkan timbulnya konflik peran. Tuntutan-tuntutan pekerjaan yang berlebihan menjadi beban bagi karyawan yang dapat menyebabkan timbulnya stress 
kerja, sehingga menurunkan kepuasan kerja karyawan. Untuk itu, diajukan perumusan pertanyaan yaitu (1) apakah konflik peran berpengaruh terhadap stres kerja karyawan?;(2) apakah stres kerja berpengaruh terhadap kepuasan kerja karyawan?;(3) apakah konflik peran berpengaruh terhadap kepuasan kerja karyawan? ; dan (4) apakah stres kerja memediasi konflik peran terhadap kepuasan kerja?

\section{Tujuan penelitian}

Adapun tujuan penelitin ini adalah untuk mengetahui dan menganalisis pengaruh konflik peran terhadap stres kerja karyawan, pengaruh kepuasan kerja terhadap stres kerja karyawan, pengaruh konflik peran terhadap kepuasan karyawan, dan pengaruh konflik peran terhadap kepuasaan kerja karyawan yang dimediasi oleh stres kerja.

\section{Manfaat penelitian:}

Hasil penelitian ini diharapkan dapat memberikan manfaat bagi manajemen PT. Jombang Intermedia Pers (Jawa Pos Radar Jombang) yang sedang berkembang dalam menentukan kebijakan yang tepat dalam mengoptimalkan potensi karyawan dan mampu mengendalikan konflik peran dan stres kerja karyawannya karena dapat berdampak pada kepuasan kerja. Selain itu, hasil penelitian ini akan memberikan tambahan informasi implementasi keilmuan manajemen sumber daya manusia terkait pengaruh konflik peran terhadap kepuasan kerja karyawan dengan stres kerja sebagai variabel mediasi dalam suatu organisasi.

\section{B. LANDASAN TEORI}

\section{Kepuasan Kerja}

Kepuasan kerja merupakan evaluasi yang menggambarkan seseorang atas perasaan sikapnya, senang atau tidak senang, puas, atau tidak puas dalam bekerja (Rivai, 2005). Sedangkan Robbins, S.P., \& Coulter, M. (2010) memiliki pendapat bahwa kepuasaan kerja adalah sikap umum seseorang terhadap pekerjaannya yang menunjukkan ada perbedaan antara jumlah penghargaan yang diterima dan jumlah yang seharusnya diterima. Dapat disimpulkan bahwa kepuasaan kerja adalah tingkat kesenangan yang dirasakan oleh seseorang atas peranan atau pekerjaannya dalam organisasi.

Terdapat dua faktor yang mempengaruhi kepuasan kerja menurut Mangkunegara (2000), yaitu faktor yang ada pada diri pegawai (meliputi: kecerdasan (IQ), kecerdasan khusus, umur, jenis kelamin, kondisi fisik, pendidikan, pengalaman kerja, masa kerja, kepribadian, emosi, cara berfikir, persepsi, dan sikap kerja) dan faktor pekerjaannya (meliputi: jenis pekerjaan, struktur organisasi, pangkat (golongan), kedudukan, mutu pengawasan, jaminan finansial, kesempatan promosi jabatan, interaksi sosial, dan hubungan kerja)

Respon terhadap ketidakpuasan kerja menurut Robbins and Judge (2009) menunjukkan empat tanggapan yang berbeda meliputi:

1. Exit

Ketidakpuasaan ditunjukkan melalui perilaku diarahkan pada meninggalkan organisasi, termasuk mencari posisi baru atau mengundurkan diri.

2. Voice

Ketidakpuasaan ditunjukkan secara pasif, tetapi optimistik dengan menunggu kondisi untuk memperbaiki, termasuk dengan 
berbicara bagi organisasi outcome negatif seperti stress kerja, dihadapan kritik eksternal dan komitmen, kepuasan dan turnover. Konflik mempercayai oragnisasi dan peran harus dikelola dengan baik karena manjemen melakukan hal yang jika diabaikan dapat meningkatkan benar.

3. Loyalty

Ketidakpuasaan ditunjukkan secara pasif, tetapi optimistik dengan menunggu kondisi untuk memperbaiki, termasuk dengan berbicara bagi organisasi di hadapan kritik eksternl dan mempercayai organisasi dan manajemen melakukan hal yang benar.

4. Neglect

Ketidakpuasaan ditunjukkan melalui tindakan secara pasif membiarkan kondisi semakin buruk, termasuk kemankiran atau keterlambatan secara kronis, mengurangi usaha, dan meningkatkan tingkat kesalahan. ketidakpastian dan menyebabkan terjadinya stres saat bekerja. Semakin kompleks konflik peran yang dialami karyawan akan semakin meningkatkan stres kerja karyawan yang berarti ada hubungan positif yang signifikan antara konflik peran dan stres kerja, Iqbal, $\mathrm{N}$. (2013) dan Yasa, I. W. M. (2017). Selain itu, semakin tinggi tingkat konflik maka kepuasan kerja karyawan akan cenderung menurun. Hal ini sesuai dengan hasil penelitian Afrizal, P. R. (2014) dan yang menunjukkan konflik kerja berpengaruh negatif dan signifikan terhadap kepuasan kerja karyawan PT.TASPEN PERSERO Cab. Malang dan didukung hasil penelitian Iqbal, N. (2013) yang menunjukkan konflik peran memiliki hubungan negatif dengan kepuasan kerja karyawan perbankan swasta di Pakistan.

\section{$\underline{\text { Konflik Peran }}$}

Konflik peran adalah keadaan yang mempengaruhi konflik peran adalah seseorang berhadapan dengan harapan sebagai berikut : (a) Masalah komunikasi peran yang berbeda, (Robbins, S. P.,\& Judge, yang dikarenakan kesalahpahaman yang T.A, 2008). Menurut Handoko konflik peran terjadi terkait kalimat, bahasa, atau adalah kondisi seseorang menjalani informasi yang kurang lengkap serta gaya pekerjaan yang tidak jelas atau pekerjaan individu yang tidak konsisten. (b) Masalah yang saling bertentangan atau diharapkan struktur organisasi karena adanya dapat melakukan pekerjaan lebih dari pertarungan kekuasaan antar departemen kemampuan, (Handoko, 2012). Tidd and dengan kepentingan-kepentingan atau Friedman (2002) dalam Rifky Indrawan sistem penilaian yang bertentangan, (2009) menyatakan konflik peran adalah situasi dimana ada perbedaan tuntutan pada seorang karyawan karena ada berbagai tindakan yang harus dilakukan. Konflik peran menyebabkan tekanan pada diri karyawan atas perbedaan tindakan yang diambil yang akan berpengaruh terhadap keadaan karyawan secara psikologis. Konflik peran dapat berpengaruh terhadap berbagai macam persaingan untuk memperebutkan sumber daya yang terbatas atau saling ketergantungan dua atau lebih kelompokkelompok kegiatan kerja untuk mencapai tujuan mereka. (c) Masalah pribadi yang biasanya karena merasa tidak sesuai dengan tujuan atau nilai-nilai sosial pribadi pegawai dengan perilaku yang diperankan pada jabatan mereka dan perbedaan persepsi. Sedarmayanti (2013) 


\section{Kerja Karyawan]}

Konflik peran dengan menggunakan dipandang tidak pasti dan penting. pengukuran yang dikembangkan oleh Sedangkan, menurut Hasibuan (2007) stres Rizzo, House dan Lirtzman (1970) dalam kerja adalah kondisi tegang yang Mas'ud (2004). Diukur dengan indikator- mempengaruhi emosi, proses berfikir dan indikator sebagai berikut:

1. Time based conflict, adalah konflik yang terjadi karena waktu yang digunakan untuk memenuhi satu peran tidak dapat digunakan untuk memenuhi peran lainnya, artinya pada saat yang bersamaan seorang yang mengalami konflik peran ganda tidak akan bisa melakukan dua peran atau lebih.

2. Strain based conflict, adalah ketegangan yang dihasilkan oleh salah satu peran membuat seseorang sulit untuk memenuhi tuntutan peran yang lain. Ketegangan yang ditimbulkan akan mempengaruhi kualitas hidup secara keseluruhan. Ketegangan peran ini termasuk stres, tekanan darah meningkat, kecemasan, cepat marah, dan sakit kepala.

3. Behaviour based conflict, adalah konflik yang muncul ketika suatu tingkah laku efektif untuk satu peran namun tidak efektif digunakan untuk peran yang lain. Ketidakefektifan tingkah laku ini dapat disebabkan oleh kurangnya kesadaran individu akan akibat dari tingkah lakunya kepada orang lain.

\section{Stres Kerja}

Stres $\begin{gathered}\text { muncul } \\ \text { seseorang }\end{gathered} \begin{aligned} & \text { dalam } \\ & \text { dalam }\end{aligned}$
memenuhi tuntutan dan harapan terhadap
dirinya, Potale, R., \& Uhing, Y. (2015).
Menurut Robbins (2008) stres adalah
keadaan yang dinamis dimana individu
dihadapkan pada suatu peluang, tuntutan,
atau sumber daya yang terkait dengan apa
yang diinginkan dengan hasilnya yang
kondisi seseorang.

Faktor-faktor yang dapat menyebabkan stres diantaranya: (a). Beban kerja yang berlebihan; (b) tekanan dan sikap pimpinan yang kurang adil dan wajar; (c) waktu dan peralatan kerja yang kurang memadai; dan (d) konflik antar pribadi dengan pimpinan atau kelompok kerja, Hasibuan (2007). Sedangkan menurut Robbins (2008) terdapat tiga sumber utama yang dapat menyebabkan timbulnya stres, yaitu: (a) faktor Organisasi, meliputi: tuntutan tugas, tuntutan peran, tuntutan antar pribadi, struktur organisasi, kepemimpinan organisasi, dan tahap perkembangan organisasi.; (b) faktor Individu, meliputi : masalah keluarga, ekonomi, dan kepribadian individu; dan (c) faktor Lingkungan, meliputi: ketidakpastian ekonomi, politik, dan teknologi.

\section{METODE PENELITIAN}

\section{Metode/Rancangan penelitian}

Penelitian ini menggunakan pendekatan kuantitatif dan bersifat kausal. Kausal adalah hubungan yang bersifat sebab akibat dimana variabel independen mempengaruhi variabel dependen (Sugiyono, 2013). Pengukuran penelitian ini menggunakan skala likert yang menurut Sugiyono (2010) skala likert digunakan untuk mengukur sikap, pendapat dan persepsi seseorang atau sekelompok orang tentang fenomena social dengan 5 poin pilihan jawaban mulai sangat tidak setuju sampai sangat setuju. Data yang digunakan dalam penelitian ini adalah data primer yaitu menggunakan angket pada seluruh karyawan PT. Jombang Intermedia Pers dan melakukan wawancara pada 
perwakilan manajemen dan karyawan. Sedangkan data sekunder dalam penelitian ini diperoleh dari PT. Jombang Intermedia Pers berupa jumlah karyawan dan urian pekerjaan, artikel jurnal, dan literatur lain yang berkaitan dengan materi kajian. Dalam penelitian ini populasi yang digunakan adalah seluruh karyawan PT. Jombang Intermedia Pers (Jawa Pos Radar Jombang) yang berjumlah 30 orang sehingga teknik penentuan sampelnya disebut sampling jenuh.

\section{Identifikasi dan Operasionalisasi Variabel}

Variabel penelitian yang digunakan dalam penelitian ini adalah variabel independen $(\mathrm{X})$, variabel dependen $(\mathrm{Y})$ dan variabel mediasi (M).

1. Konflik Peran (X)

Definisi operasional konflik peran yaitu menunjukkan kondisi konflik yang muncul ketika karyawan merasa kesulitan dalam hal menyesuaikan berbagai peran yang dimiliki dalam waktu yang bersamaan. Konflik peran diukur dengan menggunakan pengukuran yang dikembangkan oleh Rizzo, House dan Lirtzman (1970 dalam Mas'ud 2004) meliputi : Time based conflict, strain based conflict, dan behaviour based conflict

2. Stres Kerja (M)

Definisi operasional stres kerja yaitu kondisi seseorang yang tertekan karena adanya tuntutan-tuntutan lingkungan kerja berlebihan dari perusahaan yang melebihi kemampuan karyawan dan tanggapan yang ditunjukkan dalam menghadapi tuntutan-tuntutan tersebut dapat berbeda-beda. Seseorang yang mengalami stres kerja dicerminkan dari penjelasan Robbins (2008) yaitu : fisiologis, psikologis, dan perilaku.

3. Kepuasan Kerja (Y)

Definisi operasional kepuasan kerja yaitu tingkat rasa puas individu atas situasi pekerjaan dari organisasi tempat mereka bekerja. Pengukuran aspek kepuasan kerja menggunakan indikator yang dikembangkan oleh Hariandja (2002) dalam koesmono (2007) meliputi kepuasan pada pekerjaan itu sendiri, gaji, rekan kerja, atasan, kesempatan promosi, dan lingkungan kerja.

\section{Teknik Analisis Data}

Data angket online yang sudah masuk selanjutnya pada analisa deskriptif untuk melihat akarakteristik responden dan skor hasil jawaban masing-masing variabel. Selain itu, di lakukan analsis structural equation model (SEM) menggunakan alat bantu Wrap PLS 5. Menurut Ghozali (2014), Structural Equation Modeling (SEM) merupakan gabungan dari dua metode statistik yang terpisah, yaitu analisis faktor (factor analysis) yang dikembangkan di ilmu psikologi dan psikometri, serta model persamaan simultan (simultaneous equation modelling) yang dikembangkan di ekonometrika.

Dalam uji Wrap PLS di peroleh informasi hasil Outer Model dan Inner Model. Pada analisis WarpPLS, validitas diikur dengan menggunakan dua instrumen, yaitu Convergent Validity dan Discriminant Validity (Solimun, 2017). Convergent Validity merupakan korelasi antar skor indikator refleksif dengan skor variabel latennya, sedangkan Discriminant Validity merupakan pengukuran indikator refleksif dengan skor variabel latennya (Solimun, 2017). 


\section{Kerja Karyawan]}

Begitu juga untuk reliabilitas dengan analisis WarpPLS, reliabilitas diukur dengan menggunakan dua instrumen, yaitu Composite Reliability dan Alpha Cronbach (Solimun, 2017). Composite Reliability adalah kelompok indikator yang mengukur sebuah variabel memiliki reliabilitas komposit yang baik berdasarkan skor composite reliability, sedangkan Alpha Cronbach (Reliabilitas Internal Konsistensi) adalah kelompok indikator yang mengukur sebuah variabel memiliki reliabilitas komposit yang baik berdasarkan nilai koefisien alpha (Solimun, 2017).
Setelah diketahui hasil outer model dan inner model maka dapat digunakan untuk menjawab hipotesis yang dilakukan dengan melihat hasil t-test, bilamana diperoleh p-value $\leq 0,05$ (Alpha 5\%), maka dapat disimpulkan signifikan, dan begitu pula sebaliknya (Solimun, 2017).

\section{HASIL DAN PEMBAHASAN}

Karakteristik Responden

\begin{tabular}{ccc}
\multicolumn{3}{c}{ Tabel 1. Jenis Kelamin } \\
\hline \multicolumn{3}{c}{ Jenis Kelamin } \\
\hline Laki -laki & Perempuan & Total \\
24 & 6 & 30 \\
\hline
\end{tabular}

Sumber: data diolah (Spss 15.0) berada pada tugas lapangan seperti

Dari tabel 1 diatas, dapat dijelaskan wartawan dan marketing iklan. Sdangkan mayoritas responden adalah laki-laki perempuan di bidang admin. dikarenakan mayoritas bidang pekerjaan

Tabel 2. Pendidikan Terakhir

\begin{tabular}{ccc}
\hline No & Tingkat Pendidikan & Jumlah \\
\hline 1 & SMA / SMK sederajat & 5 \\
2 & D3 & 0 \\
3 & S1 & 25 \\
& Total & 30 \\
\hline
\end{tabular}

Sumber: data diolah (Spss 15.0)

pendidikan S1 merupakan kriteria

Dari tabel 2 diatas, dapat dijelaskan mayoritas pendidikan terakhir responden persyaratan untuk menjadi karyawan Radar Jombang. adalah tingkat $\mathrm{S} 1$ dikarenakan tingkat

Tabel 3. Hasil Analisis Deskriptif

\begin{tabular}{cc}
\hline Variabel & $\begin{array}{c}\text { Skor rata- } \\
\text { rata }\end{array}$ \\
\hline Konflik Peran $(\mathrm{X})$ & 3,04 \\
Stres Kerja (M) & 2,72 \\
\hline Kepuasan Kerja (Y) & 3,83 \\
\hline
\end{tabular}




\begin{tabular}{|c|c|c|}
\hline Variabel & $\begin{array}{c}\text { Composite } \\
\text { reliability } \\
\text { coffecient }\end{array}$ & $\begin{array}{c}\text { Cronbach's } \\
\text { alpha } \\
\text { coefficient }\end{array}$ \\
\hline $\mathrm{X}$ & 0,86 & 0,80 \\
\hline $\mathrm{M}$ & 0,80 & 0,70 \\
\hline $\mathrm{Y}$ & 0,93 & 0,91 \\
\hline
\end{tabular}

Berdasarkan tabel 3. menujukkan konflik peran masuk dalam kriteria cukup tinggi yang berarti bahwa mayoritas responden pernah mengalami konflik peran. Selain itu, stres kerja masuk dalam kriteria cukup yang berarti bahwa mayoritas responden sering mengalami stres walaupun tidak terus menerus. Sedangkan kepuasan kerja masuk dalam kriteria tinggi yang berarti mayoritas responden merasa puas akan pekerjaannya.

\section{Hasil Uji Outer Model}

\section{Uji Validitas}

\begin{tabular}{cccc} 
& \multicolumn{3}{c}{ Square Root Of Ave's } \\
\hline & $\mathrm{X}$ & $\mathrm{M}$ & $\mathrm{Y}$ \\
\hline $\mathrm{X}$ & 0,72 & 0,54 & 0,29 \\
$\mathrm{M}$ & 0,54 & 0,64 & 0,28 \\
$\mathrm{Y}$ & 0,29 & 0,28 & 0,73 \\
\hline
\end{tabular}

Diketahui dari 30 responden bahwa nilai root of AVE setiap variabel lebih besar dari korelasi antar variabel laten pada kolom yang sama. Sehingga menunjukkan bahwa discriminant validity dapat diterima.

2. Uji Reliabilitas

\section{Composite Reliability Dan}

Cronbach's Alpha Coefficient variabel memiliki nilai lebih dari 0,7 sehingga composite reliability diterima. Untuk cronbach's alpha pada masing-masing variabel memiliki nilai lebih dari 0,60 sehingga reliabilitas internal konsistensi diterima.

\section{Uji Goodness of Fit (Inner Model)}

Pada Analisis dengan menggunakan WarpPLS, kriteria Goodness of Fit Model dapat dilihat pada tabel berikut : composite reliability masing-masing

Model Fit Dan Quality Indiches WarpLS

\begin{tabular}{|c|c|c|c|c|}
\hline No & $\begin{array}{c}\text { Model Fit and } \\
\text { Quality Indiches }\end{array}$ & Kriteria Fit & Indeks & Kriteria \\
\hline 1 & $\begin{array}{c}\text { Average Path } \\
\text { Coefficient (APC) }\end{array}$ & $\mathrm{p}<0.05$ & 0,438 & $\begin{array}{c}\text { Terpenu } \\
\text { hi }\end{array}$ \\
\hline 2 & $\begin{array}{c}\text { Average } R-\text { squared } \\
\text { (ARS) }\end{array}$ & $\mathrm{p}<0.05$ & 0,314 & $\begin{array}{c}\text { Terpenu } \\
\text { hi }\end{array}$ \\
\hline 3 & Average Adjusted $R-$ & $\mathrm{p}<0.05$ & 0,276 & Terpenu \\
\hline
\end{tabular}


Nama Penulis [Kristin Juwita], Judul Artikel [Dampak Konflik Peran pada Stres dan Kepuasan Kerja Karyawan]

\begin{tabular}{|c|c|c|c|c|}
\hline & squared (AARS) & & & hi \\
\hline 4 & $\begin{array}{c}\text { Average block VIF } \\
\text { (AVIF) }\end{array}$ & $\begin{array}{c}\text { Acceptable if } \\
<=5 \text {, ideally <= } \\
3.3\end{array}$ & 1,012 & $\begin{array}{l}\text { Terpenu } \\
\text { hi }\end{array}$ \\
\hline 5 & $\begin{array}{c}\text { Average Full } \\
\text { Collinierity VIF ( } \\
\text { AFVIF) }\end{array}$ & $\begin{array}{l}\text { Acceptable if } \\
<=5, \text {, ideally } \\
<=3.3\end{array}$ & 1,297 & $\begin{array}{l}\text { Terpenu } \\
\text { hi }\end{array}$ \\
\hline 6 & Tanenhaus GoF (GoF) & $\begin{array}{l}\text { Small }>=0.1, \\
\text { Medium }>= \\
0.25 \\
\text { Large }>=0.36\end{array}$ & 0,413 & $\begin{array}{l}\text { Terpenu } \\
\text { hi, } \\
\text { kategori } \\
\text { large }\end{array}$ \\
\hline 7 & $\begin{array}{c}\text { Sympson's Paradox } \\
\text { Radio (SPR) }\end{array}$ & $\begin{array}{c}\text { Acceptable if } \\
>=0.7, \text { ideally }= \\
1\end{array}$ & 1,0 & $\begin{array}{l}\text { Terpenu } \\
\text { hi }\end{array}$ \\
\hline 8 & $\begin{array}{c}R-\text { squared } \\
\text { Contribution Ratio } \\
\text { (RSCR) }\end{array}$ & $\begin{array}{c}\text { Acceptable if } \\
>=0.9, \text { ideally }= \\
1 \\
\end{array}$ & 1,0 & $\begin{array}{l}\text { Terpenu } \\
\text { hi }\end{array}$ \\
\hline 9 & $\begin{array}{c}\text { Statistical } \\
\text { Suppression Ratio } \\
\text { (SSR) }\end{array}$ & $\begin{array}{l}\text { Acceptable if } \\
\quad>=0.7\end{array}$ & 1,0 & $\begin{array}{c}\text { Terpebu } \\
\text { hi }\end{array}$ \\
\hline 10 & $\begin{array}{c}\text { Nonlinear Bivariate } \\
\text { Causality Direction } \\
\text { Ratio (NLBCDR) }\end{array}$ & $\begin{array}{l}\text { Acceptable if } \\
>=0.7\end{array}$ & 1,0 & $\begin{array}{l}\text { Terpenu } \\
\text { hi }\end{array}$ \\
\hline
\end{tabular}

Sumber: Data diolah (WarpPLS 5.0)

sudah fit dengan data sehingga dapat

Berdasarkan hasil uji Goodness of melanjutkan pengujian berikutnya.

Fit diatas, dapat dijelaskan bahwa model

\section{Hasil Uji SEM WrapPLS}

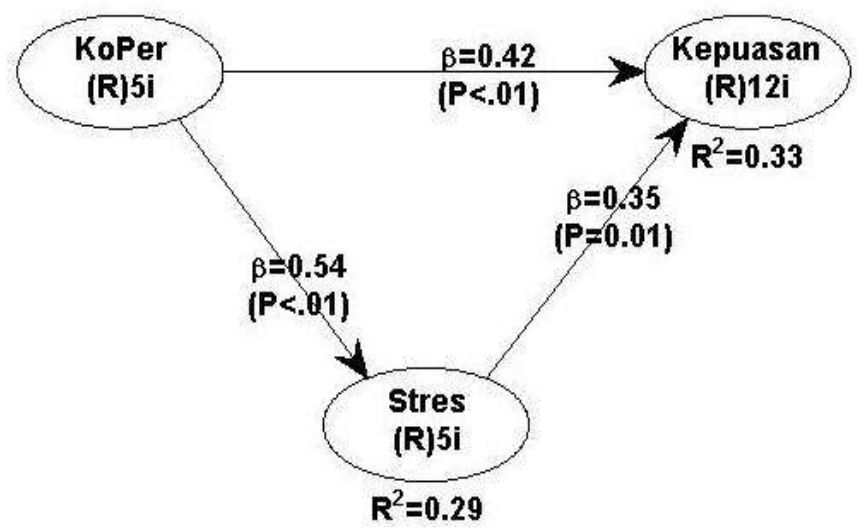

Gambar 4.1.5.1 Direct and indirect effect

Tabel 4.1.5.1 


\begin{tabular}{|c|c|c|c|c|}
\hline Kriteria & Variabel & K.Peran & Stres & $\begin{array}{l}\text { Kep.Kerj } \\
\text { a }\end{array}$ \\
\hline \multirow{3}{*}{$\begin{array}{c}\text { Path } \\
\text { coefficient }\end{array}$} & K.Peran & & 0,54 & 0,42 \\
\hline & Stres & & & 0,35 \\
\hline & Kep.Kerja & & & \\
\hline \multirow{3}{*}{$P$ values } & K.Peran & & $<0,01$ & $<0,01$ \\
\hline & Stres & & & 0,01 \\
\hline & Kep.Kerja & & & \\
\hline \multirow{3}{*}{$\begin{array}{l}\text { Effect sizes } \\
\text { for path }\end{array}$} & K.Peran & & 0,29 & \\
\hline & Stres & & & 0,33 \\
\hline & Kep.Kerja & & & \\
\hline $\begin{array}{l}\text { Indirect } \\
\text { Effect }\end{array}$ & \multicolumn{4}{|c|}{$\begin{array}{l}\text { Konflik Peran -> Stres -> Kepuasan } \\
\text { dengan } \beta(0,191) \text { dan } p \text {-value }(0,057)\end{array}$} \\
\hline
\end{tabular}

\section{Path Coefficients}

Sumber: data diolah (WarpPLS 5.0)

\section{Pembahasan}

\section{Pengaruh konflik peran terhadap stres kerja karyawan.}

Hasil penelitian menunjukkan bahwa konflik peran berdampak pada peningkatan stres kerja karyawan yang berarti apabila semakin sering terjadi konflik peran akan mengakibatkan meningkatnya stres kerja karyawan. Karyawan Radar Jombang sering mengerjakan beberapa tugas yang harus diselesaikan dalam waktu yang bersamaan sehingga mengalami stres karena dirasa tidak efektif dalam segi waktu dan tenaga. Bentuk stres yang dirasakan yaitu merasa kelelahan, tegang, mudah tersinggung dan bahkan dengan banyaknya pekerjaan yang harus diselesaikan membuat karyawan menyalahkan pekerjaan orang lain. Hasil penelitian ini memperkuat penelitian Iqbal, N. (2013) memberikan hasil bahwa adanya hubungan positif yang signifikan antara konflik peran dan stres kerja. H1diterima.

\section{Pengaruh konflik peran terhadap} kepuasan kerja karyawan.

Hasil penelitian ini menunjukkan bahwa konflik peran berdampak positif terhadap kepuasan kerja karyawan. Hal ini bertolak belakang pada hipotesis yang

diajukan yaitu berpengaruh negatif bukannya positif. Dalam realitanya karyawan Radar Jombang masih merasakan adanya kesesuaian antara harapan dalam diri mereka dengan peran yang dijalankan. Karyawan menyadari jika pekerjaan mereka memang berat, namun pekerjaan tersebut semestinya dikerjakan. Walaupun karyawan dihadapkan pada berbagai macam pekerjaan yang menyebabkan konflik peran, namun karyawan masih mampu mengontrol diri dari kesadaran terhadap tanggung jawab pekerjaan yang harus diperhatikan sehingga kepuasan kerja karyawan tetap terjaga. Banyaknya pekerjaan tetap membuat karyawan merasa puas terhadap sarana dan prasarana yang mendukung penyelesaian pekerjaan, serta dukungan dari rekan kerja maupun General Manager. Karyawan Radar Jombang memberikan respon yang positif terhadap adanya tuntutan pekerjaan dan tanggung jawab, namun tidak berarti karyawan tidak puas terhadap pekerjaan mereka. Penelitian ini sejalan dengan penelitian Melly (2004) dalam Churiyah, M. (2011) yang menyatakan bahwa ada 


\section{Kerja Karyawan]}

hubungan positif antara konflik peran dan kepuasan kerja. Namun, hasil penelitian ini tidak didukung oleh Yousef (2000) mengemukakan bahwa seseorang yang mengalami konflik peran dan ambiguitas peran pada tingkat yang tinggi sebagai sumber dari stres akan kurang puas dengan pekerjaannya. H2 Di tolak

\section{Pengaruh stres kerja terhadap kepuasan kerja karyawan.}

Hasil penelitian ini menunjukkan bahwa stres kerja berdampak positif terhadap kepuasan kerja karyawan. Hal ini berbanding terbalik dengan hipotesis yang diajukan yaitu berpengaruh negatif bukannya positif. Stres yang dirasakan karyawan radar Jombang merupakan stres yang positif, dimana seseorang semakin terpacu untuk mengerahkan segala kemampuan dan sumberdaya-sumberdaya yang dimilikinya agar dapat memenuhi persyaratan dan kebutuhan kerja. Terkadang ada individu yang saat menghadapi beban kerja yang berat menjadi merasa tertantang untuk dapat menyelesaikannya sehingga akan lebih rajin dan giat dalam mencapai target yang telah dibebankan. Sehingga individu yang demikian tidak merasakan stres dalam pekerjaannya tetapi merasa lebih bersemangat untuk bekerja memenuhi target.

Hasil penelitian ini memperkuat penelitian sebelumnya yang dilakukan HANIM, M. L. (2016) yang menunjukkan ada hubungan positif yang signifikan antara stres kerja dengan kepuasan kerja. McGee, G. W., Goodson, J. R., \& Cashman, J. F. (1987) mendapati bahwa beberapa faktor yang menyebabkan pegawai mengalami stres kerja tetapi masih merasa puas terhadap pekerjaannya. Hal ini diantaranya disebabkan oleh tugas yang mereka kerjakan penuh dengan tantangan dan menyenangkan hati mereka. Selain itu terjadi komomunikasi yang efektif di antara para anggota dalam organisasi tersebut. H3 Ditolak.

\section{Pengaruh stres kerja dalam memediasi konflik peran terhadap kepuasan kerja karyawan.}

Hasil penelitian ini menunjukkan bahwa stres kerja tidak mampu memediasi pengaruh konflik peran terhadap kepuasan kerja karyawan. Dalam penelitian ini konflik peran mempunyai hubungan yang positif dan berpengaruh secara langsung terhadap kepuasan kerja karyawan. Dalam kenyataan di lapangan, karyawan Radar Jombang memang merasakan adanya stres kerja namun hanya pada saat-saat tertentu, misalnya pada akhir dan awal bulan ketika deadline semua pekerjaan bersamaan waktu pengerjaan dan pelaporannya.

Hasil penelitian ini tidak mendukung hasil penelitian terdahulu dari Khattak et al. (2013) dan Ain et al. (2013) dalam Rohmawati, I. S. N. (2016) yang menyatakan bahwa stres kerja memediasi pengaruh antara ambiguitas peran dan konflik peran terhadap kepuasan kerja.

Konflik peran yang dialami oleh karyawan Radar Jombang dapat teratasi dengan adanya dukungan dan kekomapkan dari rekan kerja serta atasan dan juga komunikasi yang intensif dan efektif. Rekan kerja dan atasan yang membantu dan selalu mendukung dalam kondisi pekerjaan yang berat dapat menurunkan tingkat ketegangan pada karyawan, sehingga kepuasan dengan rekan kerja dan atasan yang dirasakan oleh karyawan pun akan meningkat. Komunikasi yang terjalin dengan baik juga dapat mengurangi terjadinya konflik peran, karena informasiinformasi penting dalam melakukan pekerjaan dapat tersampaikan dengan baik. H4 ditolak. 


\section{PENUTUP}

Berdasarkan penelitian di peroleh kesimpulan bahwa konflik peran berperan dalam meningkatkan stres kerja karyawan dan kepuasan kerja karyawan. Selain itu, stres kerja berdampak positif pada kepuasan kerja karyawan yang menunjukkan bahwa jika terjadi peningkatan pada stres kerja maka kepuasan kerja karyawan meningkat karena diimbangi dengan adanya keterbukaan komunikasi dan kekompakan tim kerja, serta kesadaran karyawan terhadap tanggung jawab. Hasil penelitian juga menunjukan stres kerja tidak mampu memediasi pengaruh konflik peran terhadap kepuasan kerja karyawan.

Berdasarkan hasil penelitian di atas, maka dapat diberikan saran kepada perusahaan untuk melakukan evaluasi proses kerja sehingga mengurangi terjadinya konflik peran terhadap karyawan. Hal itu bisa dilakukan dengan mengurangi tuntutan peran pekerjaan yang melebihi sumber daya yang dimiliki karyawan. Selain itu, menjalin komunikasi yang lebih baik antar karyawan maupun dengan atasan juga dapat meminimalisir terjadinya konflik peran. Adapun kepuasan kerja karyawan sudah baik dan perlu dipertahankan, peruasahaan sebaiknya memberikan upah lembur kepada karyawan yang melakukan tugas diluar jam kerjanya atau diadakan gathering untuk seluruh karyawan guna lebih mempererat tali persaudaran. Perusahaan juga lebih meningkatkan fasilitas yang diberikan untuk karyawan, seperti meningkatkan kenyamanan sarana prasarana penunjang pekerjaan karyawan, misalnya komputer serta kebersihan lingkungan kantor. Stres kerja yang dialami oleh karyawan adalah hal wajar, namun apabila terlalu sering akan menimbulkan dampak buruk bagi karyawan itu sendiri. Untuk itu, karyawan Radar Jombang perlu meningkatkan kesadaran diri dan memahami bahwa pekerjaan tersebut memang sudah menjadi tanggung jawabnya. Untuk penelitian selanjutnya, diharapkan untuk mengungkap hasil penelitian sejenis yang menjadi research gap bagi stressor yang berdampak pada kepuasan kerja karyawan, karena hasil penelitian ini menujukan konflik peran menjelaskan kepuasan kerja sangatlah rendah dan stres kerja tidak mampu menjadi mediasi antara konflik peran dan kepuasan kerja karyawan.

\section{DAFTAR PUSTAKA}

A, P. R. (2014). Pengaruh konflik kerja dan stres kerja terhadap kepuasan kerja (studi pada karyawan PT. TASPEN (PERSERO) cabang Malang). Jurnal Administrasi Bisnis, 8(1).

A, N. M., Suprapti, N. W. S., \& Sintaasih, D. K. (2016). Peran Kepuasan Kerja Dalam Memediasi Pengaruh Konflik Peran Dan Stres Kerja Terhadap Intensi Keluar (Studi Pada Anantara Seminyak Resort \& Spa, Bali). JURNAL RELASI STIE MANDALA JEMBER, 12(1)..

C, M. (2011). Pengaruh konflik peran, kelelahan emosional terhadap kepuasan kerja dan komitmen organisasi. Jurnal Ekonomi Bisnis, 16(2), 145-154.

G, I. 2014. Model Persamaan Struktural : Konsep dan Aplikasi dengan Program AMOS 22. Semarang: BP Undip

H, T. Hani. 2008. Manajemen Personalia dan Sumber Daya Manusia, Edisi kedua. Yogyakarta: BPFE 
H, T. Hani. 2012. Manajemen Personalia dan Sumber Daya Manusia. Yogyakarta: BPFE

H, M. L. (2016). Pengaruh Stres Kerja Terhadap Kepuasan Kerja Serta Dampaknya Pada Kinerja Karyawan Hull Construction Di Pt. Dok Dan Perkapalan Surabaya.Jurnal Ilmu Manajemen (JIM), 4(3).

http://corporate.jawapos.com/businesssection\#business-section-media. Diakses: 31 januari 2018

I, R. (2009). PENGARUH KONFLIK PERAN TERHADAP STRES KERJA DENGAN KETIDAKPASTIAN DAN KEPUASAN KERJA SEBAGAI VARIABEL MEDIASI (Studi Pada PT. Air Mancur Karanganyar) (Doctoral dissertation, Universitas Sebelas Maret).

I, N. (2013). Impact of Role Conflict on Job Satisfaction, Mediating Role of Job Stress in Private Banking Sector. Interdisciplinary Journal of Contemporary Research In Business, $14,711-722$

K, H. T. (2007). Pengaruh kepemimpinan dan tuntutan tugas terhadap komitmen organisasi dengan variabel moderasi motivasi perawat rumah sakit swasta Surabaya. Jurnal Manajemen dan Kewirausahaan, 9(1), pp-30.

M, S. P. Hasibuan 2007. Manajemen Sumber Daya Manusia. Jakarta: PT. Bumi Aksara

M, A. A. P. (2000). Manajemen sumber daya manusia perusahaan. Remaja Rosdakarya.

M, F. 2004. Survai Diagnosis Organisasional, Konsep dan Aplikasi.
Semarang: Badan Penerbit Universitas Diponegoro

M, G. W., Goodson, J. R., \& Cashman, J. F. (1987). Job stress and job dissatisfaction: Influence of contextual factors. Psychological Reports, 61(2), 367-375.

M, M., \& Hidayati, L. A. (2017). PEMODELAN STRES KERJA DALAM MENDORONG INTENSITAS KELUAR.Jurnal Analisis Bisnis Ekonomi, 15(1), 54-64.

N, I. R., H, T., \& Maria, S. (2017). Pengaruh konflik peran, ambiguitas peran dan stres kerja terhadap kinerja karyawan. Jurnal Manajemen, 8(1), 118.

P, R., \& Uhing, Y. (2015). Pengaruh Kompensasi dan Stres Kerja Terhadap Kepuasan Kerja Karyawan Pada PT. Bank Sulut Cabang Utama Manado.Jurnal EMBA: Jurnal Riset Ekonomi, Manajemen, Bisnis dan Akuntansi, 3(1).

R, S. P., \& Coulter, M. (2010). Manajemen. Jakarta: Erlangga.

R, S. P., \& Judge, T. A. (2008). Perilaku Organisasi (Terjemahan) Edisi Keduabelas Buku Dua. Jakarta: PT. Salemba Empat.

R, S. P., \& Judge, T. A. (2009). Organizational Behavior (Perilaku Organisasi) Terj. Diana Angelica dkk, Jakarta.

R, I. S. N. (2016). Pengaruh ambiguitas peran terhadap kepuasan kerja karyawan dengan stres kerja sebagai variabel mediasi pada PT. Waskita beton precast plant Sidoarjo. 
S. 2013. Manajemen Sumber Daya Manusia. Bandung: Refika Aditama

S. 2017. Penguatan Confirmatory Research : Pemodelan Persamaan Struktural Pendekatan WarpPLS. Malang: Universitas Brawijaya

S. (2010). Metode Penelitian Kuantitatif, Kualitatif dan R\&D. Bandung: Alfabeta.CV

S. (2013). Metode Penelitian Kuantitatif, Kualitatif dan R\&D.Bandung: Alfabeta.CV

W, A. D., \& Sugianingrat, I. W. (2015). Effect of multiple role conflict on job satisfaction with the mediation role of stress. International Journal of Economics, Commerce and Management, 3(5), 868-870.

Y, I. W. M. (2017). Pengaruh Konflik Peran dan Ambiguitas Peran Terhadap Kinerja Pegawai Melalui Mediasi Stres Kerja Pada Dinas Kesehatan Kota Bali.Jurnal Ekonomi \& Bisnis, 4(1), 38-57.

Y, D. A. (2000). The interactive effects of role conflict and role ambiguity on job satisfaction and attitudes toward organizational change: A moderated multiple regression approach. International Journal of Stress Management, 7(4), 289-303.

Y, R. H. (2008). Pengaruh flexible work arrangement terhadap role conflict, role overload, reduced personal accomplishment, job satisfaction dan intention to stay. Jurnal Bisnis dan Akuntansi, 10(3), 127-138. 